\title{
TINGKAT KONTROL SOSIAL INTERNAL MAHASISWA TERHADAP PERILAKU CYBERBULLYING DI MEDIA SOSIAL
}

\author{
Ainul Zulqoifah A ${ }^{1}$, Dadang Hikmah Purnama ${ }^{2}$, Waspodo ${ }^{3}$ \\ ${ }^{1,2,3}$ Program Studi Magister Sosiologi \\ Fakultas Ilmu Sosial dan Ilmu Politik Universitas Sriwijaya Palembang, Kode Pos 30121 \\ Alamat e-mail: ${ }^{1}$ ainul.zulqoifah@gmail.com
}

\begin{abstract}
Abstrak
Penggunaan media sosial yang semakin populer saat ini memperbesar terjadinya perilaku cyberbullying dikalangan mahasiswa sebagai pengguna aktif media sosial, oleh karena itu untuk melakukan pencegahan sedini mungkin perlu dilakukan kajian ilmiah untuk menganalisis perilaku cyberbullying dengan melihat kemungkinan faktor penyebabnya. Penelitian ini bertujuan untuk mengetahui tingkat kontrol sosial internal mahasiswa dan menganalisis pengaruhnya terhadap perilaku cyberbullying mahasiswa di Kota Palembang. Metode penelitian yang digunakan adalah kuantitatif dengan pendekatan ex-post facto. Hasil penelitian menemukan bahwa tingkat kontrol sosial internal mahasiswa tergolong tinggi atau kuat. Kontrol sosial melalui ikatan sosial yang terjalin antara mahasiswa dengan keluarga dan universitas berpengaruh secara negatif dan signifikan terhadap perilaku cyberbullying dengan nilai t-hitung -3,664dan nilai signifikasi 0,000 .
\end{abstract}

Kata Kunci: kontrol sosial internal; media social; perilaku cyberbullying;

\begin{abstract}
The use of social media that increasingly popular nowadays, increases the occurrence of cyberbullying behavior among college students as social media active users, therefore to take precautions as early as possible it is necessary to conduct scientific studies for analyzing cyberbullying behaviour by looking at the possible causes. The purpose of this study is to find out the level of students internal social control and analyze its effects on the cyberbullying behavior of students in the city of Palembang. Method used in this research was quantitative with ex-post facto approach. The results found that students' social control was classified as high or strong. Social control through the social ties that exist between students and families and universities has a negative and significant impact on cyberbullying behavior with a $t$-value of -3.664 and a significance value of 0.000.
\end{abstract}

Keywords: internal social control; social media; cyberbullying behavior;

\section{PENDAHULUAN}

Penggunaan produk teknologi informasi berupa media sosial seperti facebook, twitter, dan instagram di era digital saat ini menjadi salah satu cara terdepan bagi organisasi, perusahaan bahkan individu dalam berkomunikasi dan bersosialisasi. Media sosial telah menjelma sebagai ruang baru yang sangat diminati oleh masyarakat indonesia untuk berinteraksi dan bersosialisasi, hal ini dibuktikan dengan hasil laporan dari We Are Social bersama Hootsuite (2018) 
bahwa dalam kurun waktu satu tahun yaitu 2017 hingga 2018 pertumbuhan pengguna media sosial di indonesia meningkat hingga 23 persen.

Selain manfaat yang dirasakan, kehadiran media sosial juga membawa serta dampak negatif bagi penggunanya salah satu dampak tersebut adalah terjadinya cyberbullying diantara penggunanya. Menurut agensi anti intimidasi yaitu Ditch the Label (2018) berdasarkan hasil survei yang dilakukan terhadap lebih dari 10.020 pemuda mengungkapkan bahwa 69 persen pemuda mengaku melakukan sesuatu yang kasar terhadap orang lain secara online di media sosial dan 42 persen dari pemuda yang telah diintimidasi secara online mengklaim bahwa intimidasi tersebut terjadi di media sosial. Perilaku cyberbullying merupakan perbuatan yang dilakukan dengan sengaja menggunakan media sosial untuk mempermalukan ataupun mengejek/menghina orang lain, menyampaikan berita yang salah, serta menyampaikan informasi yang tidak benar tentang orang lain (O'Keeffe dan Pearson, 2011).

Untuk mencegah dan mengontrol terjadinya perilaku cyberbullying tersebut pemerintah telah mengeluarkan Undang-Undang No. 11 Tahun 2016 tentang Informasi dan Transaksi Elektronik (ITE), dalam undang-undang ITE pada pasal 45A dan 45B dijelaskan bahwa perundungan di dunia siber (cyberbullying) akan dipidana dengan pidana penjara paling lama 4 (empat) tahun. Namun sebagai upaya pemerintah untuk melakukan pengendalian dengan memberikan hukuman kepada pelaku, Undang-Undang ITE tidak sepenuhnya memberikan efek jera kepada pelaku cyberbullying, fakta di lapangan mengungkapkan bahwa perilaku cyberbullying di media sosial masih sering terjadi. Seperti halnya di wilayah Sumatera Selatan menurut data yang diperoleh dari Laporan Direktorat Reserse Kriminal Khusus (DIRESKRIMSUS) (2018), Kepolisian Negara Republik Indonesia Daerah Sumatera Selatan mengungkapkan bahwa perilaku cyberbullying di kalangan remaja masih cenderung tinggi data tesebut mennjukkan sebanyak 47 persen pelaku cyberbullying merupakan remaja akhir dengan usia 18-25 tahun.

Fakta tersebut diatas menunjukkan bahwa aktivitas cyberbullying juga terjadi dikalangan mahasiswa sebagai representasi dari usia remaja akhir, penelitian (Febrianti, 2014) memperkuat fakta bahwa cybebullying juga terjadi pada kalangan 
mahasiswa, hasil penelitian yang dilakukan pada mahasiswa Univeritas Indonesia menemukan bahwa sebanyak 77 persen mahasiswa pernah terlibat dalam cyberbullying. Cyberbullying menjadi sebuah permasalahan sosial karena menyangkut tata kelakuan yang immoral, berlawanan dengan hukum dan bersifat merusak. Menurut psikolog klinis Widyarini (Irwan, 2018) dampak cyberbullying bagi pelaku adalah mereka tidak mampu untuk mengembangkan empati dan memiliki kesiapan mental yang cenderung untuk menyimpan skrip (kesiapan bertindak) ageresi, dengan dampak seperti yang dikemukakan tersebut maka sebuah kajian secara mendalam terhadap perilaku cyberbullying sangatlah diperlukan, mengingat mahasiswa merupakan generasi penerus bangsa yang mencerminkan karakter bangsa sehingga diharapkan memiliki perilaku yang sesuai dengan normanorma yang berlaku dalam masyarakat serta memiliki jiwa yang sehat.

Rafferty (2011) melalui penelitiannya mengungkapkan bahwa cyberbullying terjadi karena kurangnya rasa menghormati dan menghargai orang lain, dan kurangnya nilai-nilai moral yang bertentangan dengan penyimpangan yang dimiliki oleh remaja. Merujuk pada hasil penelitian tersebut diketahui bahwa kurangnya nilai-nilai moral yang dimiliki remaja memiliki hubungan dengan perilaku cyberbullying, serta adanya fakta di lapangan yang mengungkapkan bahwa pengendalian yang telah dilakukan oleh pemerintah melalui Undang-Undang ITE masih belum mampu untuk mengendalikan perilaku cyberbullying di media sosial, maka analisis terkait kontrol sosial internal untuk memahami perilaku cyberbullying di media sosial menjadi penting untuk dilakukan karena mengacu pada relasi antara individu dengan masyarakat seperti institusi sosial yaitu keluarga dan sekolah atau lembaga pendidikan formal, hingga peer group (kelompok pertemanan) yang mensosialisasikan norma dan nilai dimasyarakat serta membawa individu kepada penyesuaian dan ketaatan pada aturan-aturan dalam masyarakat.

Kontrol sosial internal dari Hirschi (1996) memiliki ide utama yang menyatakan bahwa kejahatan dan perilaku menyimpang merupakan perilaku alami yang akan muncul kecuali dicegah oleh ikatan yang terjalin dalam lembaga konvensional. Berdasarkan pandangan dari teori kontrol sosial maka dapat diasumsikan bahwa perilaku cyberbullying merupakan salah satu wujud dari 
perilaku menyimpang yang disebabkan oleh adanya kekosongan kontrol sosial atau lemahnya kontrol sosial (ikatan sosial) yang mengikat antara individu dengan institusi prososial yaitu keluarga terutama orang tua, sekolah (pendidik) dan teman sebaya (peers). Perilaku cyberbullying dikategorikan sebagai perilaku penyimpang karena menyangkut tata kelakukan yang immoral, berlawanan dengan hukum dan bersifat merusak.

Ikatan sosial yang terjalin antara individu dengan institusi prososial ini dapat dilihat berdasarkan empat komponen ikatan sosial yang telah dikemukakan oleh Hirschi (1996) yaitu kelekatan, komitmen, keterlibatan dan keyakinan. Menurut Hirschi (1996) kelekatan sebagai salinan sosial dari super ego atau hati nurani yang berkaitan dengan kepedulian, kepekaan serta koneksi psikologis dan emosional yang dirasakan individu terhadap individu lainnya ataupun kelompok memiliki pengaruh terhadap perilaku menyimpang yang dilakukan individu, keterkaitan tersebut diperlihatkan dalam hasil penelitian dari Bayraktar dkk. (2014) menemukan bahwa kelompok cyberbully (pelaku) memiliki kelekatan (attachment) dengan orang tua yang lemah, dan memiliki korelasi yang kuat dengan pelilaku cyberbulling.

Komponen ikatan sosial selanjutnya adalah komitmen individu yang disebut Hirschi (1969) sebagai salinan secara sosiologis dari ego (akal sehat), sehingga komitmen dapat dilihat sebagai hasil dari pendekatan untung-rugi (cost-benefit) dalam berperilaku (Shoemaker, 1996). hasil penelitian yang dilakukan oleh Asanan, Hussain, dan Laidey (2017) menemukan bahwa penalaran moral atau akal sehat (common sense) dan pertimbangan, yang digunakan untuk memprediksi cyberbullying memiliki hubungan positif yang signifikan dengan kegiatan cyberbullying di kalangan mahasiswa. Selanjutnya komponen keterlibatan (involvement) memiliki kaitan dengan komponen komitmen, karena berkaitan dengan kesadaran akan konsekuensi yang diperoleh dari melakukan tindakan menyimpang. Penelitian yang dilakukan oleh Lee and Wu (2018) yang membahas mengenai hubungan antara sikap, pengaruh sosial, dengan intensi cyberbullying menemukan bahwa ketika remaja melihat cyberbullying sebagai perilaku yang salah dan tidak memenuhi etika, maka intensi (niat) mereka untuk menggunakan 
pendekatan negatif yang sama ketika memperlakukan orang lain akan berkurang. Oleh karena itu, kemungkinan untuk mengembangkan perilaku cyberbullying akan berkurang.

Selanjutnya Hirschi (1969) mengungkapkan bahwa keyakinan (belief) yang berkaitan dengan kesetiaan seseorang terhadap nilai dan kode moral yang disosialisasikan dalam kelompok, jika kode moral dan nilai yang disampaikan kelompok menyatakan bahwa tindakan menyimpang tertentu salah, maka individu yang meyakini kode moral dan nilai tersebut akan menunjukkan kesetian dengan tidak ikut serta dalam tidakkan menyimpang. Penelitian yang dilakukan oleh Dilmaç dan Aydo (2010) menemukan bahwa nilai-nilai kemanusiaan (human value) secara signifikan menjelaskan perilaku cyberbullying ketika dianalisis secara individual. Dalam konteks ini, individu yang memegang pertimbangan moral akan cenderung untuk tidak melakukan perilaku cyberbullying. Kesimpulan yang dapat diambil dari uraian diatas adalah bahwa kelekatan, komitmen, keterlibatan, serta keyakinan yang merupakan sebuah rangkaian dari kontrol sosial internal dapat diasumsikan sebagai penyebab terjadinya perilaku cyberbulling.

\section{METODE}

Penelitian ini menggunakan metode kuantitatif expost-facto. Populasi penelitian merupakan mahasiswa perguruan tinggi negeri (PTN) yang di Kota Palembang. Sampel penelitian ditentukan berdasarkan teknik purposive sampling dengan pertimbangan karakteristik populasi yaitu: a) mahasiswa dengan usia 18-25 tahun; b) pengguna aktif media sosial; dan c) pernah melakukan cyberbullying. Penentuan ukuran atau jumlah responden penelitian ditetapkan dengan rumus Lemeshow dkk. (1990) dengan tingkat kepercayaan sebesar 95\% dan diperoleh responden sebanyak 117 mahasiswa. Untuk menjamin keterwakilan mahasiswa dari kedua universitas dilakukan kembali pengambilan sampel secara stratified dan didapatkan 59 sampel untuk universitas berbasis agama yaitu Universitas Islam Negeri Raden Fatah (UIN Raden Fatah) dan 58 sampel dari universitas bukan berbasis agama yaitu Universitas Sriwijaya (UNSRI). 
Pengumpulan data dilakukan dengan menggunakan kuesioner. Variabel kontrol sosial dan perilaku cyberbullying diukur menggunakan skala yang dibuat oleh peneliti yaitu skala kontrol sosial yang merujuk pada teori kontrol sosial dari Hirschi (1969) dan skala cyberbullying dari Williard (Rastiti, 2016), skala tersebut telah teruji keabsahan dan keterandalannya. Adapun teknik analisis yang digunakan adalah analisis statistik diskriptif untuk melihat tingkat kontrol sosial mahasiswa dan analisis regresi linear sederhana yang digunakan untuk mengukur pengaruh variabel kontrol sosial internal terhadap variabel terikat yaitu perilaku cyberbullying serta digunakan untuk mengetahui arah hubungan antara variabel independen dengan variabel dependen.

\section{HASIL DAN PEMBAHASAN}

\section{Hasil}

\section{Perilaku Cyberbullying di Media Sosial Pada Mahasiswa}

Hasil analisis deskripsi menemukan bahwa dari 117 sampel secara keseluruhan mahasiswa sebagian besar mahasiswa di Kota Palembang yaitu 95,7 persen berada pada kategori perilaku cyberbullying yang rendah dengan gambaran komposisi kategorisasi data sebagai berikut:

\section{Tabel 1. Kategorisasi Perilaku Cyberbullying}

\begin{tabular}{cccccc}
\hline & & Frequency & Percent & Valid Percent & Cumulative Percent \\
\hline \multirow{3}{*}{ Valid } & Rendah & 112 & 95,7 & 95,7 & 95,7 \\
\cline { 2 - 6 } & Sedang & 5 & 4,3 & 4,3 & 4,3 \\
\cline { 2 - 6 } & Tinggi & 0 & 0 & 0 & 100,0 \\
\cline { 2 - 6 } & Total & 117 & 100,0 & 100,0 & \\
\hline
\end{tabular}

Presentase kategori perilaku cberbullying yang "rendah" tersebut memiliki peberbedaan jumlah presentase ketika perilaku cyberbullying dilihat berdasarkan asal universitas mahasiswa. Perbedaan presentase tersebut digambarkan dalam bentuk grafik sebagai berikut: 


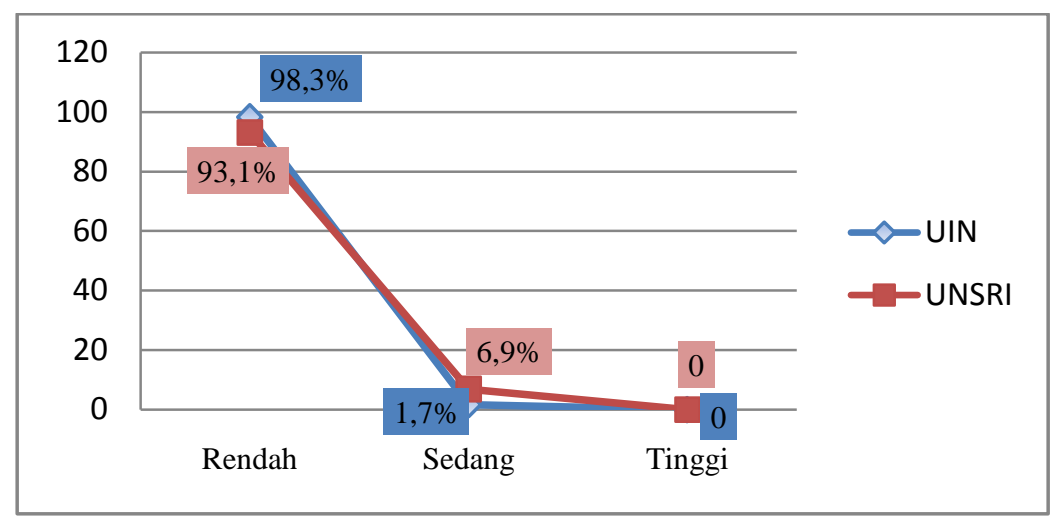

\section{Gambar 1. Kategorisasi Perilaku Cyberbullying Mahasiswa Berdasarkan Universitas}

Berdasarkan grafik yang terlihat pada gambar 1 dapat diketahui bahwa mahasiswa dari UIN Raden Fatah memiliki presentase perilaku cyberbullying rendah sebesar 98,3 persen. Hal ini menunjukkan bahwa dibandingkan dengan mahasiswa UNSRI, jumlah mahasiswa UIN Raden Fatah yang berada pada kategori perilaku cyberbullying rendah lebih banyak 6,3 persen dari mahasiswa UNSRI. Adapun bentuk dari perilaku cyberbullying yang paling banyak dilakukan mahasiswa adalah perilaku harasmhent yaitu mengunggah atau mem-posting pesan dengan kalimat kasar, kejam hingga mengolok-olok orang lain dimedia sosial dengan presentase distribusi skor dari jawaban responden sebesar 37,43 persen.

Selanjutnya jika dikaitkan dengan jenis kelamin responden. Antara responden mahasiswa laki-laki dan perempuan, mahasiswa perempuan muncul sebagai pelaku perilaku cyberbullying yang paling dominan dengan jumlah sebanyak 89 mahasiswa perempuan dan hanya 28 mahasiswa laki-laki. Adapun jenis bentuk cyberbullying yang cenderung untuk dilakukan mahasiswa perempuan adalah harashment (pelecehan) yang dilakukan dengan cara berulang-ulang menunggah/mem-posting pesan kasar, kejam/mengolok-olok kepada individu yang dijadikan sebagai target/korban. Bentuk harashment ini memiliki presentase distribusi skor jawaban responden tertinggi yaitu sebesar 37,36 persen. Untuk mahasiswa laki-laki bentuk cyberbullying yang cenderung banyak dilakukan adalah flamming 38,57 persen dan impersonating 36,14 persen. 


\section{Tingkat Kontrol Sosial Internal Mahasiswa}

Penelitian ini menemukan bahwa sebagian besar mahasiswa di kota pelambang berada pada kategori kontrol sosial internal yang "tinggi" atau "kuat", hal ini ditunjukkan dalam hasil kategori data yang memperlihatkan bahwa 98 persen mahasiswa berada pada kategori tinggi, dengan komposisi kategorisasi kontrol sosial sebagai berikut:

Tabel 2. Kategorisasi Data Kontrol Sosial

\begin{tabular}{llcccc}
\hline & & Frequency & Percent & Valid Percent & Cumulative Percent \\
\hline \multirow{2}{*}{ Valid } & Rendah & 0 & 0 & 0 & 0 \\
\cline { 2 - 6 } & Sedang & 19 & 16,2 & 16,2 & 16,2 \\
\cline { 2 - 6 } & Tinggi & 98 & 83,8 & 83,8 & 100,0 \\
\cline { 2 - 6 } & Total & 117 & 100,0 & 100,0 & \\
\hline
\end{tabular}

Kategori kontrol sosial internal ini memiliki perbedaan presentase apabila didasarkan pada asal universitas mahasiswa yang memilki latar belakang berbeda, dengan perbedaan presentase yang digambarkan dalam bentuk grafik sebagai berikut:

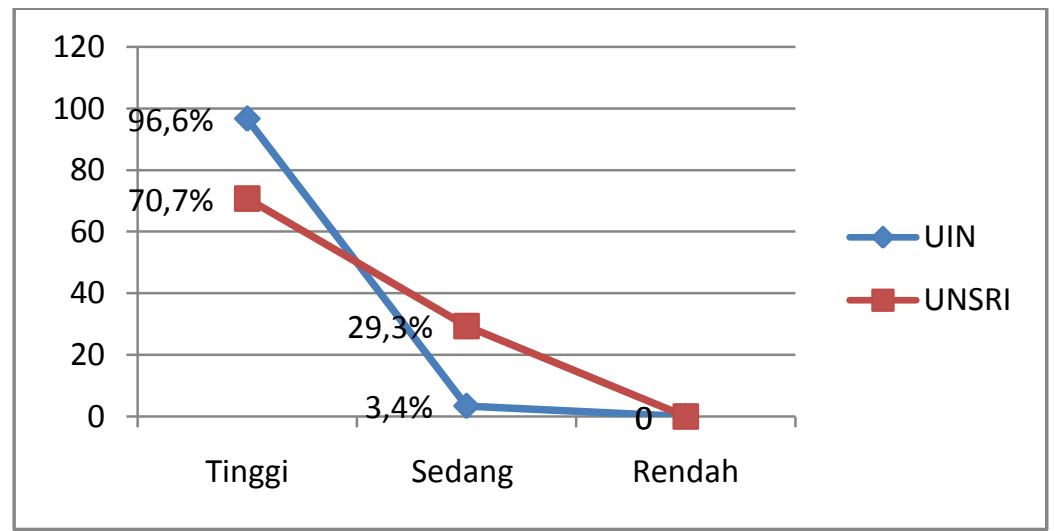

\section{Gambar 2. Kategorisasi kontrol sosial internal Mahasiswa Berdasarkan Universitas}

Berdasarkan pada gambar 2 diketahui bahwa mahasiswa UIN Raden Fatah memiliki presentase kontrol sosial internal pada kategori "sedang" hingga "tinggi" yang lebih banyak dibandingkan UNSRI. Pada kategori tinggi/kuat mahasiswa UIN Raden Fatah memiliki presentase sebesar 96,6 persen sedangkan UNSRI hanya sebanyak 70,7 persen. Bahkan untuk kategori sedang kontrol sosial tersebut memiliki perbedaan presentase yang sangat mencolok yaitu 3,4 persen untuk 
mahasiswa UIN Raden Fatah, 29,3 persen untuk mahasiswa UNSRI. Hasil tersebut memberikan gambaran bahwa hampir sepertiga dari mahsiswa UNSRI memiliki kontrol sosial yang "sedang", sedangkan mahasiswa UIN Raden Fatah secara keseluruhan hampir memiliki kontrol sosial internal yang tinggi.

Tingginya kontrol sosial internal mahasiswa ditunjukkan dengan keseluruhan nilai presentase skor distribusi jawaban responden pada setiap dimensi yang cenderung tinggi seperti pada indikator dimensi kelekatan (attachment) yang berisikan tentang pernyataan terkait koneksi psikologis dan emosional yang dirasakan seseorang dan sejauh mana individu peduli tentang pendapat dan perasaan orang tua, dosen, dan teman sebaya. Presentase skor pada indikator kelekatan secara keseluruhan adalah 83,56 persen dengan kelekatan kepada orang tua dan teman sebaya yang paling dominan diantara tiga kelekatan yang terjalin tersebut. Kemudian untuk dimensi yang memiliki nilai presentase yang rendah diantara dimensi lainnya adalah dimensi keterlibatan (involvement) dengan skor distribusi jawaban secara keseluruhan indikator sebesar 61,53 persen. Indikator ini berisikan pertanyaan yang digunakan untuk melihat keterlibatan ataupun partisipasi responden dalam kegiatan konvensional yang ada di tempat tinggal dan Universitas.

\section{Pengaruh Kontrol Sosial internal Terhadap Perilaku Cyberbullying}

Hasil analisis regresi linier sederhana yang menunjukkan pengaruh kontrol sosial internal terhadap perilaku cyberbullying mahasiswa disajikan dalam tabel berikut:

Tabel 3. Hasil Uji t

\begin{tabular}{|c|c|c|c|c|}
\hline & Unstandardized Coefficients & $\begin{array}{l}\text { Standardized } \\
\text { Coefficients }\end{array}$ & & \\
\hline Model & Std. Error & Beta & $\mathrm{t}$ & Sig. \\
\hline (Constant) & 36,313 & & 12,402 &, 000 \\
\hline Kontrol Sosial &,- 135 &,- 323 & $-3,664$ &, 000 \\
\hline
\end{tabular}

Hasil pengujian yang disajikan dalam tabel 3 menunjukkan bahwa terjadi pengaruh negatif antara variabel kontrol sosial internal terhadap perilaku cyberbullying karena adanya nilai koefisien regresi yang didapatkan bernilai minus, 
sehingga model persamaan regresi yang didapatkan adalah $\mathrm{Y}=36,313-0,135 \mathrm{X}$. Untuk signifikansi koefisien regresi diketahui nilai signifikasi (Sig.) yang didapatkan adalah 0,000 artinya lebih kecil dari nilai probabilitas yang di gunakan yaitu 0.05 maka dapat disimpulkan bahwa ada pengaruh antara kontrol sosial internal dengan perilaku cyberbullying mahasiswa dengan arah pengaruh pada area negatif.

Adapun besaran kontribusi pengaruh yang diberikan variabel kontrol sosial internal terhadap perilaku cyberbullying disajikan dalam tabel 4 berikut:

Tabel 4. Nilai Koefisien Determinasi $\left(\boldsymbol{R}^{2}\right)$

\begin{tabular}{llr}
\hline Model & $\mathrm{R}$ & R Square \\
\hline 1 &, $343^{\mathrm{a}}$ &, 117 \\
\hline
\end{tabular}

a. Predictors: (Constant), Kontrol Sosial

Nilai koefisien determinasi sebesar 0,105 ini mengandung arti bahwa kontrol sosial $\left(\mathrm{X}_{1}\right)$ dan intensitas penggunaan media sosial $\left(\mathrm{X}_{2}\right)$ secara simultan (bersama-sama) berpengaruh terhadap perilaku cyberbullying (Y) sebesar 11,7 persen sedangkan 88,3 persen sisanya dipengaruhi oleh variabel lain yang tidak diteliti dalam penelitian ini.

\section{Pembahasan}

Hasil penelitian ini juga menemukan bahwa sebagian besar mahasiswa yang berasal dari universitas dengan latar belakang agama memiliki kontrol sosial internal yang tinggi dibandingkan mahasiswa yang berasal dari universitas dengan latar belakang umum, temuan tersebut menunjukkan bahwa lingkup kehidupan sosial mahasiswa memiliki andil yang besar dalam menentukan tingkatan kontrol sosial internal pada mahasiswa. Selain itu, hasil penelitian ini juga menunjukkan bahwa variabel kontrol sosial internal dan perilaku cyberbullying memiliki pengaruh yang tidak searah, sehingga ketika variabel kontrol sosial internal mahasiswa mengalami peningkatan (tinggi) maka perilaku cyberbullying di media sosial akan mengalami penurunan (rendah). Hasil temuan pengaruh yang tidak searah atau berpengaruh negatif ini sejalan dengan teori kontrol sosial Hirschi 
(Hagan, 2013) yang menyatakan bahwa lemah dan kuatnya kontrol sosial internal seseorang dapat dilihat melalui ikatan sosial individu dengan institusi prososial (keluarga dan pendidikan/sekolah). Ketika bentuk ikatan sosial yang mengikat seseorang melemah atau putus maka dapat membebaskan seseorang tersebut untuk terlibat dalam perilaku menyimpang/kenakalan. Selain itu hasil penelitian ini juga selaras dengan hasil penelitian yang dilakukan oleh Chantelle (2017) yang menjelaskan bahwa ikatan sosial yang terjalin dengan teman sebaya memiliki pengaruh negatif terhadap cyberbullying meskipun didukung oleh variabel moderator.

Pengaruh yang tidak searah ini dapat disebabkan oleh keadaan mahasiswa sebagai remaja yang berada pada usia 18 hingga 25 tahun secara kognitif menurut Piaget (Papalia, 2009) telah mampu untuk berhadapan dengan ide-ide dan nilainilai secara logis sehingga dapat membayangkan suatu rekaan kejadian yang berupa kemungkinan proposisi abstrak diolah dengan pemikiran logis, dengan keadaan intelektual tersebut maka mahasiswa akan memiliki kecenderungan untuk menghindari perilaku cyberbullying dengan melakukan pendekatan untung-rugi (cross-benefit) yang didapatkan dalam melakukan perilaku tersebut.

Alasan lainnya dari kecenderungan mahasiswa menghindari perilaku cyberbullying di media sosial tersebut adalah sebagai individu yang menyandang sebagai individu yang berpendidikan maka mahasiswa tidak ingin terlihat buruk didepan orang tua, dosen dan teman sebayanya. Kesadaran akan kerugian terlihat buruk inilah yang menjadikan mahasiswa memiliki perilaku cyberbullying rendah. Hal ini sejalan dengan teori Hirschi (1969) yang menyebutkan bahwa dalam kontrol sosial internal terdapat komitmen sebagai salah satu komponen yang merupakan salinan sosiologis dari ego (akal sehat) berupa kesadaran seseorang bahwa mereka akan kehilangan "sesuatu" yang berharga saat melakukan perilaku meyimpang sehingga menahan diri untuk tidak berperilaku menyimpang. Kesadaran akan akibat dari tindakan yang dilakukan tersebut ditunjukkan dengan distribusi skor jawaban responden pada dimensi komitmen yaitu sebesar 82,73 persen, dengan indikator berupa komitmen terhadap peraturan yang ditunjukkan dengan pernyataan berupa 
"saya memahami kerugian yang saya peroleh dimasa depan, jika melakukan pelanggaran pada aturan yang ada di tempat tinggal dan kampus".

Selain disebabkan oleh adanya pendekatan cross-benefit, kuatnya kelekatan yang terjalin antara mahasiswa dengan orang tua, pendidik dan temen sebaya juga memiliki andil terhadap rendahnya perilaku cyberbullying mahasiswa di Kota Palembang. Kelekatan yang tinggi tersebut ditunjukkan degan hasil distribusi skor jawaban mahasiswa pada dimensi kelekatan yang tinggi yaitu 83,56 persen, presentase tersebut memiliki arti bahwa kelekatan yang terjalin antara mahasiswa dengan orang tua sebagai ikatan emosional dapat mengembangkan hati nurani (super ego) yang cukup sehingga mahasiswa peduli dan memikirkan terlebih dahulu reaksi orang tua, dosen dan teman ketika akan melakukan perilaku menyimpang yaitu cyberbullying, kelekatan yang terjalin tersebut kemudian menguatkan mahasiswa untuk tetap berkomitmen agar tidak melakukan perilaku merugikan seperti cyberbullying yang dapat berdampak pada hilangnya kepercayaan dari orang terdekat serta hingga tercoreng citra dirinya sebagai individu yang berpendidikan dimata orang lain sebaga akibat dari tindakan tidak terpuji yaitu perilaku cyberbullying.

Kemudian keterlibatan mahasiswa pada aktivitas konvensional yang rendah yaitu 64.61 persen dibandingkan dimensi lainnya ini dapat menjadi alasan mengapa perilaku cyberbullying masih terjadi di kalangan mahasiswa, dengan keterlibatan dalam aktivitas konvensional yang rendah maka mahasiswa masih memilki waktu untuk mengakses media sosial dengan frekuensi dan durasi yang berlebih yang akhirnya memicu terjadinya perilaku cyberbullying. Alasan tersebut sejalan dengan teori kontrol sosial yang dikemukakan oleh Hirschi (1996) bahwa ketika seseorang terlalu sibuk melakukan kegiatan konvensional maka seseorang tersebut tidak akan memiliki waktu untuk terlibat dalam perilaku menyimpang.

Nilai besaran keofisien determinasi menunjukkan bahwa variabel kontrol sosial internal memberikan kontribusi sebesar 11,7 persen dalam menjelaskan perilaku cyberbullying. Nilai koefisien determinasi yang tergolong lemah bukan berarti pengaruh kontrol sosial merupakan prediktor yang tidak baik atau tidak dapat digunakan untuk memprediksi perilaku cyberbullying, dalam penjelasan 
Moksony dan Heged (1990), nilai $R$ square (keofisien determinasi) yang rendah menunjukkan bahwa variabel dependen dipengaruhi oleh sejumlah faktor lain selain yang dipertimbangkan dalam analisis, meskipun demikian nilai $R$ square ini dalam penelitian yang membangun hubungan sebab akibat tidaklah penting karena penelitian ini tidak bertujuan untuk mempersiapkan daftar lengkap dari berbagai penyebab dari suatu fenomena.

Adapun variabel atau faktor- lainnya yang tidak diteliti dalam penelitian ini seperti kontrol diri yang dijelaskan dalam penelitian dari Malihah (2018) bahwa kontrol diri pada remaja memiliki hubungan negatif degan perilaku cyberbullying dengan nilai kontribusi sebesar 15,2 pesen. Kemudian penelitian dari Lucas (2018) yang menjelaskan bahwa jenis kelamin dan perbedaan asosiasi yang dimiliki individu memiliki hubungan yang positif dengan perilaku cyberbullying dengan nilai kontribusi sebesar 16,6 persen. Dengan melihat bahwa kontribusi yang diberikan oleh masing-masing variabel cenderung berada pada nilai hubungan dan pengaruh terhadap perilaku cyberbullying yang rendah maka dapat disimpulkan bahwa terjadinya perilaku cyberbullying dapat dipengaruhi oleh banyak variabel yang tidak diteliti dalam penelitian ini sehingga mengakibatkan nilai kontribusi yang berikan memiliki presentase yang rendah (lemah).

Selain itu, nilai $R^{2}$ yang relatif rendah yaitu 11,7 persen ini memiliki kaitan dengan bidang studi atau cakupan ilmu dalam penelitian ini yang memprediksikan perilaku manusia, seperti penjelasan dari Gray (Onditi, 2013) yang mengungkapkan bahwa penelitian pada bidang ilmu apa pun yang mencoba memprediksi perilaku manusia, seperti psikologi, biasanya memiliki nilai $R$-squared yang lebih rendah dari 20\%. Hal ini diakrenakan manusia lebih sulit diprediksi dari pada proses fisik, sehingga nilai $R$-squared yang didapakan pada umumnya bernilai rendah. Akan tetapi meskipun nilai $R$-squared rendah, jika tingkat signifikansi dan menunjukkan bahwa variabel prediktor memiliki pengaruh yang signifikan secara statistik, maka kesimpulan penting masih dapat ditarik tentang bagaimana perubahan dalam nilai variabel prediktor berkaitan dengan perubahan nilai pada variabel respon. 


\section{SIMPULAN}

Tingkat kontrol sosial internal pada mahiswa di kota pelambang sebagian besar berada pada kategori "tinggi" atau "kuat". Akan tetapi, tingkat kontrol sosial internal ini memiliki presentase yang berbeda jika dilihat berdasarkan asal universitas mahasiswa temuan tersebut menunjukkan bahwa lingkup kehidupan sosial mahasiswa memiliki andil yang besar dalam menentukan tingkatan kontrol sosial internal pada mahasiswa. Kontrol sosial internal mahasiswa berpengaruh secara signifikan terhadap perilaku cyberbullying, sehingga dapat diartikan bahwa semakin optimal kontrol sosial internal yang dilakukan melalui ikatan sosial antara mahasiswa dengan orang tua maupun perguruan tinggi maka kemungkinan terjadinya perilaku cyberbullying mahasiswa akan semakin rendah, dengan hasil tersebut maka disarankan bagi orang tua dan pendidik untuk terus memperkuat ikatan sosial dengan mahasiswa dengan cara membangun kelekatan agar remaja dapat mengembangkan hati nuraninya dengan baik sehingga peduli dan memikirkan reaksi maupun pendapat orang lain sebelum melakukan perilaku yang merugikan seperti cyberbullying. Selain itu, pemerintah perlu untuk mensosialisasikan kepada mahasiswa dan remaja sebagai pengguna aktif media sosial terkait etika dalam mengakses media sosial (nettiquete) sehingga memahami batasan penggunaan dan lebih berhati-hati dalam berkomunikasi dan menggunkan media sosial.

\section{DAFTAR PUSTAKA}

Asanan, Zsa, Zsa Tajol, Ibiwani Alisa Hussain, and Nooraneda Mutalip Laidey. 2017. "A Study on Cyberbullying: Its Forms , Awareness and Moral Reasoning Among Youth." International Journal of Information and Communication Sciences page: 2(5): 54-58.

Bayraktar, Fatih, Hana Machackova, Lenka Dedkova, and Alena Cerna. 2014. "Cyberbullying: The Discriminant Factors Among Cyberbullies, Cybervictims, and in a Czech Adolescent Sample". Journal of Interpersonal Violence. Page: 1-25.

Chantelle A. Cummings. 2017. "I Can't See You, You Can't See Me: Cyberbullying: An Exploratory Study Examining this concept through the Lens of the Social Bond Theory". International Journal of Criminal \& 
Forensic Science. 1:2, Page : 32-39.

Dilmaç, Bülent and Didem Aydo. 2010. "Values as a Predictor of Cyber-Bullying Among Secondary School Students". International Journal of Computer and Systems Engineering 4(3):1035-38.

Ditch, The Label. 2018. The Annual Bullying Report. United Kingdom.

Febrianti, Rianda dan Gagan Hartana. 2014. "Cyberbullying Pada Mahasiswa Universitas". $\quad$ http://lib.ui.ac.id/naskahringkas/2016-06/S56877Rianda\%20Febrianti.

Hagan, Frank E. 2013. Pengantar Kriminologi: Teori, Metode, Dan Perilaku Kriminal. Jakarta: kecana.

Hirschi, Travish. 1996. Cause of Delinquency. Berkeley: University of California Press.

Irwan, dodi. 2018. "Sikap nyiyir di media sosial, apakah gangguan mental?". Artikel. www.liputan6.com/health/read/3236125.

Lee, Yi-chih and Wei-li Wu. 2018. "Factors in Cyber Bullying: The AttitudeSocial Influence-Efficacy Model". Jurnal anales de psicología. 34(2010):324-31.

Lemeshow, Stanley, David W. Hosmer Jr, Janelle Klar, and Stephen K. Lwanga. 1990. Adequacy of Sample Size in Health Studies. England: Jhon Willey \& Sons Ltd.

Lucas, Kwellin. 2018. "Cyber-bullying Among Collage Students: A Test of Social Learning Theory". Theses and Dessertations (All): Indiana University of Pennsylvania. https://knowledge.library.iup.edu/etd/1644.

Malihah, Zahro and Child Communication. 2018. "Cyberbullying among Teenager and Its Relationship with Self-Control and Parents- Child Communication". Jur. Ilm. Kel. \& Kons 11(2):145-56.

Moksony, Ferenc and Rita Heged. 1990. "small is beautiful. the use and interpretation of $\mathrm{r} 2$ in social research". Szociológiai Szemle (Special issue): $130-38$.

https://www.researchgate.net/publication/242329609_Small_Is_Beautiful_T he_Use and_Interpretation_of_R2_in_Social_Research.

Onditi, Arvinlucy A. 2013. "Relationship between Customer Personality, Service Features and Customer Loyalty in the Banking Sector: A Survey of Banks in Homabay County, Kenya". International Journal of Business and Social Science 4(15):132-50. 
Rafferty, Rebecca S. 2011. "Motivation Behind Cyber Bullying and Online Aggression: Cyber Sanctions, Dominance, and Trolling Online." Thesis .Ohio Uiversity.

We are Sosial and Hootsuite. 2018. "Digital In 2018 Essential Insights Into Internet, Social Media, Mobile, And Ecommerce Use Around The World". https://hootsuite.com/.../Digital-in-2018-001-Global-Overview-Reportv1.02-L.pdf. 